ISSN 2083-3725

Volume 10, No. 4, 2017
Authors' contribution/

Wkład autorów:

A. Zaplanowanie badań/

Study design

B. Zebranie danych/

Data collection

C. Analiza statystyczna/

Statistical analysis

D. Interpretacja danych/

Data interpretation

E. Przygotowanie tekstu/

Manuscript preparation

F. Opracowanie

piśmiennictwa/

Literature search

G. Pozyskanie funduszy/

Funds collection

\section{THE QUALITY OF THE WEBSITES OF AGRITOURISM FARMS IN VISEGRAD GROUP COUNTRIES IN THE LIGHT OF SELECTED SYNTHETIC MEASURES}

\section{JAKOŚĆ WITRYN INTERNETOWYCH GOSPODARSTW AGROTURYSTYCZNYCH KRAJÓW GRUPY WYSZEHRADZKIEJ W ŚWIETLE WYBRANYCH MIAR SYNTETYCZNYCH}

\author{
Karol Król \\ University of Agriculture in Krakow \\ Uniwersytet Rolniczy im. Hugona Kołłątaja w Krakowie
}

Król K. (2017), The quality of the websites of agritourism farms in Visegrad Group countries in the light of selected synthetic measures/Jakość witryn internetowych gospodarstw agroturystycznych krajów Grupy Wyszehradzkiej w świetle wybranych miar syntetycznych. Economic and Regional Studies, Vol. 10, No. 4, pp. 76-85. https://doi.org/10.29316/ers-seir.2017.36

\section{Summary}

ORIGINAL ARTICLE

Subject and purpose of work: The aim of the work was to evaluate the quality of the websites of agritourism farms in the Visegrad Group countries.

JEL code: R58, L86. Materials and methods: Evaluation of website quality was based on selected "site authority" measures, from the so-called SEO metrics: Trust Rank, Moz Rank and Page Authority, as well as measurement of the selected performance parameters of websites. The research was conducted on a group of 400 websites of agritourism farms, whose addresses were obtained from selected web directories.

Results: In the case of as many as 331 sites (approx. 83\%) Trust Rank lower than 1 point was recorded. The majority of tested websites are characterised by an average value of the Moz Rank index and a low value of the Page Authority index. The average time taken to load the website in the browser window for the first time was about 2.7 seconds, with as many as $68(17 \%)$ websites being loaded in over 5 seconds. Conclusions: The tested websites are characterised by low values of the authority index, which may indicate poor quality, poor visibility in search results and a lack of recommendations from other valuable sites. Low index values may also mean that, despite the global potential, the tested websites have a merely local impact. Their existence is known to a small number of people and their Internet visibility is negligible or nonexistent. Websites published in such a manner do not fulfil their function.

Keywords: promotion of agritourism, website optimisation, SEO metrics

\section{Streszczenie}

ORYGINALNY ARTYKUŁ NAUKOWY

Klasyfikacja JEL: R58, L86.

Zgłoszony:

Maj 2017

Zaakceptowany:

Czerwiec 2017

Tabele: 3

Rysunki: 1

Literatura: 27
Przedmiot i cel pracy: Celem pracy była ocena jakości witryn internetowych gospodarstw agroturystycznych krajów Grupy Wyszehradzkiej.

Materiały i metody: Ocene jakości witryn przeprowadzono w oparciu o wybrane miary „autorytetu witryn”, z grona tzw. „miar SEO” (ang. SEO metrics): Trust Rank, Moz Rank oraz Page Authority, a także pomiar wybranych parametrów wydajności witryn. Badania przeprowadzono w zbiorze 400 witryn gospodarstw agroturystycznych, których adresy pozyskano z wybranych katalogów witryn.

Wyniki: W przypadku aż 331 witryn (ok. 83\%) odnotowano wskaźnik Trust Rank mniejszy od 1 punktu. Większość testowanych witryn charakteryzowała przeciętna wartość wskaźnika MozRank oraz niska wartość wskaźnika Page Authority. Przeciętny czas pierwszego wczytania witryny w oknie przeglądarki wyniósł około 2,7 sekundy, przy czym aż 68 (17\%) z testowanych witryn wczytana została w czasie powyżej 5 sekund.

Wnioski: Testowane witryny charakteryzowała niska wartość wskaźników autorytetu, co może świadczyć o ich złej jakości, niewielkiej widoczności w wynikach wyszukiwania oraz braku rekomendacji płynących z innych, wartościowych witryn. Niskie wartości wskaźników mogą także oznaczać, że pomimo globalnego potencjału, testowane witryny oddziaływują lokalnie. 0 ich istnieniu wie niewielka liczba osób, a ich widoczność w Internecie jest znikoma lub żadna. Tak opublikowane witryny nie spełniają swojej funkcji.

Słowa kluczowe: promocja agroturystyki, optymalizacja witryn, SEO metrics

Address for correspondence/ Adres korespondencyjny: dr inż. Karol Król, Uniwersytet Rolniczy im. Hugona Kołłątaja w Krakowie, Wydział Inżynierii Środowiska i Geodezji, Katedra Gospodarki Przestrzennej i Architektury Krajobrazu, al. Mickiewicza 24/28, p.244, 30-059 Kraków, Polska; tel. +48 12 662 40 16; e-mail: k.krol@onet.com.pl; ORCID 0000-0003-0534-8471

Journal indexed in/ Czasopismo indeksowane w: AgEcon Search, AGRO, BazEkon, Index Copernicus Journal Master List, ICV 2016: 92,91; Polish Ministry of Science and Higher Education 2016: 9 points/ AgEcon Search, AGRO, BazEkon, Index Copernicus Journal Master List ICV 2016: 92.91; Ministerstwie Nauki i Szkolnictwa Wyższego 2016: 9 punktów. Copyright: (C) 2017 Pope John Paul II State School of Higher Education in Biała Podlaska, Karol Król. All articles are distributed under the terms of the Creative Commons Attribution-NonCommercial-ShareAlike 4.0 International (CC BY-NC-SA 4.0) License (http://creativecommons.org/licenses/by-nc-sa/4.0/), allowing third parties to copy and redistribute the material in any medium or format and to remix, transform, and build upon the material, provided the original work is properly cited and states its license. 


\section{Introduction}

The Visegrad Group (V4) was established in 1991 as an informal association of three Central and Eastern Europe countries: Poland, Czechoslovakia and Hungary. Its purpose was to intensify the cooperation between Central European countries. Following the division of Czechoslovakia, which took place on 1st January 1993, the group comprised: Poland, Hungary, Czech Republic and Slovakia (Dangerfield 2008).

The Visegrad Group seeks to strengthen Central European identity within the European Union and promotes regional cooperation of Central European countries (Törő et al. 2014). It is a platform of regional cooperation. It is based on a common historical heritage and similar geopolitical situation.

The Visegrad Group has no extensive administrative structures. Its only institution is the Secretariat of the International Visegrad Fund with its headquarters in Bratislava. The fund supports non-governmental organisations through numerous grants for programs in the fields of culture, science and education, and supports international exchange, cross-border cooperation and promotion of tourism. The latter alone develops very dynamically in V4 countries, especially in rural areas (Abrham 2014). This is due to, inter alia, the increase in the quality of services provided by agritourism farms, competitive prices, diversified offer and geopolitical conditions, which in recent years have significantly influenced the preferences of tourists.

In the last decade, the Internet has become one of the main channels for dissemination of information about tourism products and services. Online advertising and promotion are growing in popularity. The advantages of the Internet have also been recognised by agritourism farms, whose owners increasingly often use the Internet to promote the services they provide. In order to perform their function, websites should display valuable content and should be carefully created from the technical perspective. The technique of their design and the quality of the presented contents condition their effectiveness, which, in turn, can be expressed using a variety of synthetic measures, including: website (domain) authority indices, usage and performance statistics as well as goal conversion index. The aim of the study was to evaluate the quality of the websites of agritourism farms in the Visegrad Group countries based on the analysis of selected synthetic measures.

\section{Selected factors that determine the quality of websites}

Internet technologies are developing dynamically. Websites that met design standards a few years ago may now be outdated both in terms of design technology and graphics. Thus, following the changing trends and technological development becomes a necessity.

\section{Wstęp}

Grupa Wyszehradzka (V4) powstała w 1991 r. jako nieformalne zrzeszenie trzech państw Europy Środkowo-Wschodniej: Polski, Czechosłowacji i Węgier. Celem jej powstania było pogłębianie współpracy między państwami środkowoeuropejskimi. Po podziale Czechosłowacji, który miał miejsce 1 stycznia 1993 r. w skład grupy weszły: Polska, Węgry, Czechy i Słowacja (Dangerfield 2008).

Grupa Wyszehradzka zabiega o wzmocnienie tożsamości Europy Środkowej w ramach Unii Europejskiej i promuje współpracę regionalną krajów środkowoeuropejskich (Törő i in. 2014). Jest platformą współpracy regionalnej. Jej fundament stanowi wspólne dziedzictwo historyczne i zbliżona sytuacja geopolityczna.

Grupa Wyszehradzka nie ma rozbudowanych struktur administracyjnych. Jedyną jej instytucją jest Sekretariat Międzynarodowego Funduszu Wyszehradzkiego z siedzibą w Bratysławie. Fundusz wspiera organizacje pozarządowe poprzez liczne granty dla programów w dziedzinie kultury, nauki i edukacji oraz wspomaga wymianę międzynarodową, współpracę przygraniczną i promocję turystyki. Ta z kolei rozwija się w krajach V4 bardzo dynamicznie, w szczególności na terenach wiejskich (Abrham 2014). Wynika to między innymi ze wzrostu jakości usług świadczonych przez gospodarstwa agroturystyczne, konkurencyjnych cen, zróżnicowanej oferty i uwarunkowań geopolitycznych, które w ostatnich latach znacząco wpłynęły na zmianę preferencji turystów.

$\mathrm{W}$ ostatnim dziesięcioleciu jednym z podstawowych kanałów rozpowszechniania informacji o produktach i usługach turystycznych stał się Internet. Reklama i promocja w sieci cieszą się rosnącą popularnością. Zalety Internetu dostrzegły także gospodarstwa agroturystyczne, których właściciele coraz częściej wykorzystują witryny internetowe do promocji świadczonych usług. Witryny internetowe, aby spełniały swoją funkcję powinny prezentować wartościowe treści i być starannie wykonane od strony technicznej. Technika ich wykonania oraz jakość prezentowanych treści warunkują ich efektywność. Ta z kolei może być wyrażona przy pomocy różnych miar syntetycznych, w tym: wskaźników autorytetu witryny (domeny), statystyk użytkowania i wydajności, a także wskaźnika konwersji celu. Celem pracy była ocena jakości witryn internetowych gospodarstw agroturystycznych krajów Grupy Wyszehradzkiej w oparciu o analizę wybranych miar syntetycznych.

\section{Wybrane czynniki decydujące o jakości witryn in- ternetowych}

Technologie internetowe rozwijają się dynamicznie. Witryny internetowe, które jeszcze kilka lat temu spełniały standardy projektowe, mogą być obecnie przestarzałe, zarówno pod względem techniki wykonania, jak i oprawy graficznej. Podążanie za zmieniającymi się trendami i rozwojem technologicznym staje się więc koniecznością. 
The fact that websites and social media may aid the promotion of services provided is obvious to most agritourism farms owners (Krzyżanowska 2014). However, the effectiveness of using these tools may vary (higher, lower or even none) and depends on many factors, which can be influenced and the effects of this influence can be measured. This knowledge is regarded as specialised, but it can be crucial and may determine the competitive advantage.

The quality of a website consists of many factors. They may include the scope and theme of the presented content as well as the form of its presentation; site design technique (in terms of engineering, repertoire of solutions) including correct code syntax (Król 2015a); number of functionalities available, degree of interactivity, usability as well as graphic design. In these areas, there are a number of guidelines, standards and design practices which determine the quality of a site. These, in turn, evolve towards conversion-oriented systems, i.e. achieving specific results, achieving the goal (Jankowski 2011, Król 2017). The activities undertaken in a website's surroundings, such as those on social media and industry portals, are also determined by its successfulness. Enclosing attractive and unique content, optimization of technical parameters and active promotion can have a significant impact on the perception of the site by users (Król 2016). In addition, there is a correlation between the form of publication and the quality of content posted on web pages and their visibility. Sites that are ranked high in search results are rich in content in addition to being functional and technically well-designed (Król, 2015b).

\section{Research on the quality of websites of agritourism farms}

Websites of agritourism farms are most often examined for completeness of content (contents) and the extent of functionality and interactivity features available. These features are usually awarded points and the site classified according to the adopted systematics. Beldon and Cai (2006) noted that the improvement of website quality and making more efficientuse of theInternetcan contributeto developing tourism in rural areas. They researched 50 sites of agritourism farms in the United States of America. They evaluated the parameters characterizing their content, interactivity and promotion tools. They demonstrated in their conclusion that the sites they had reviewed were of static character and played a negligible role in promoting their farms. Havlíček and co-authors (2013) evaluated 60 websites of agritourism farms in the Czech Republic basing on the criterion of content quality (content, completeness, relevance). The results obtained were compared with the results of the studies conducted in 2009 (Havlíček et al. 2009) and showed that the overall quality of the websites of Czech agritourism farms had increased slightly only in the quality of the content presented.
To, że witryny internetowe i media społecznościowe mogą wspomóc promocję świadczonych usług jest dla większości właścicieli gospodarstw agroturystycznych oczywiste (Krzyżanowska 2014). Efektywność wykorzystania tych narzędzi może być jednak różna (mniejsza lub większa, a nawet żadna), i zależna od wielu czynników, na które można wpływać i mierzyć efekty tego wpływu. Wiedza ta jest traktowana jako specjalistyczna, jednak może być kluczowa i decydować o przewadze konkurencyjnej.

$\mathrm{Na}$ jakość witryny internetowej składa się wiele czynników. Zaliczyć do nich można zakres oraz tematykę prezentowanych treści, a także formę jej prezentacji; technikę wykonania serwisu (w ujęciu inżynierskim, warsztatowym), w tym poprawność składniową kodu (Król 2015a); liczbę udostępnianych funkcjonalności, stopień interaktywności, użyteczność, a także oprawę graficzną. W obszarach tych występuje szereg założeń, standardów i praktyk projektowych, które decydują o jakości witryny. Te z kolei ewoluują w kierunku systemów zorientowanych na konwersję, czyli osiąganie określonych rezultatów, realizację wyznaczonych celów (Jankowski 2011, Król 2017). O sukcesie witryny decydują także działania podejmowane $\mathrm{w}$ jej otoczeniu $\mathrm{np}$. $\mathrm{w}$ mediach społecznościowych i na portalach branżowych. Redagowanie atrakcyjnych i unikalnych treści, optymalizacja technicznych parametrów oraz aktywna promocja mogą mieć znaczący wpływ na postrzeganie witryny przez użytkowników (Król 2016). Ponadto istnieje zależność pomiędzy formą publikacji i jakością treści zamieszczanych na stronach internetowych, a ich widocznością. Witryny, które są plasowane na wysokich miejscach w wynikach wyszukiwania są bogate $w$ treści, funkcjonalne i dobrze wykonane technicznie (Król 2015b).

\section{Badania jakości witryn internetowych gospo- darstw agroturystycznych}

Witryny internetowe gospodarstw agroturystycznych są najczęściej badane pod kątem kompletności treści (zawartości) oraz zakresu udostępnianych funkcjonalności i interaktywności. Cechy te są zwykle punktowane, a witryny klasyfikowane według przyjętej systematyki. Beldona i Cai (2006) zauważyli, że poprawa jakości witryn i efektywniejsze wykorzystanie Internetu może wspomóc rozwój turystyki na obszarach wiejskich. Zbadali oni 50 witryn gospodarstw agroturystycznych ze Stanów Zjednoczonych Ameryki. Oceniali parametry charakteryzujące ich treść, interaktywność i narzędzia promocji. W konkluzji wykazali, że oceniane witryny miały charakter statyczny i pełniły znikomą rolę $\mathrm{w}$ promocji gospodarstw. Havlíček i współautorzy (2013) ocenili 60 witryn internetowych gospodarstw agroturystycznych z Republiki Czeskiej, w oparciu o kryterium jakości treści (zawartość, kompletność, aktualność). Uzyskane wyniki porównali z wynikami badań przeprowadzonych w 2009 r. (Havlíček i in. 2009) i wykazali, że ogólna jakość witryn internetowych czeskich gospodarstw agroturystycznych wzrosła nieznacznie, jedynie w zakresie jakości prezentowanych treści. 
Platania (2014) evaluated the websites of agritourism farms located in Sicily (Italy) using the eMICA model (Doolin et al. 2002). He showed that within the set of the investigated sites the most numerous ones were those characterized by a low level of interactivity. In addition, most of them fulfilled only the function of information provision. Zopounidis and co-authors (2014) verified the content of Greek agritourism websites including the presence of the following information on these websites: services, pricing, contact details, contact form and guestbook.

Website surveys of agritourism farms and other entities providing accommodation in rural areas are also conducted based on user feedback. Herrero and San Martín (2012), based on interviews with users of websites presenting agritourism accommodation facilities, showed that the usefulness of a website is a major factor influencing the customer's intention to use it for service booking. They also proved that interactivity and ease to navigate are essential to encourage visitors to browse the site. San Martín and Herrero (2012) examined the process of the reception of new information technology by the users of agritourist websites.

Krzyżanowska (2014) analyzed trends of changes in information and promotion activities in rural tourism and their effectiveness. In another work, she characterized the objectives and tools of promotion, sources of information about the offer of agritourism farms preferred by tourists, and evaluated the design quality of the sites of selected agritourism farms located in Podlaskie Vivodeship (Krzyżanowska, Wojtkowski 2012). Dziechciarz (2011) examined the sites of agritourism farms in Lubuskie Voivodeship. He assessed the substantive content of the services and the ability to contact and book a service online. An analogous method of research was applied by Kosmaczewska (2010), who assessed the sites of agritourism farms located in Greater Poland Voivodeship. Stepaniuk (2012), in turn, examined the functionality of the websites of farms in eastern Poland. Król (2015b) searched for dependencies between the design technology of agritourism websites and their visibility in search results, while Król and Bedla (2015) examined 300 websites of Polish agritourism farms and showed that only a small portion of them was adapted to mobile devices. Ammirato (2010) conducted a study of 176 agritourism farms in Calabria, Italy, and drew attention to the slow introduction of e-commerce by the surveyed entities. In turn, Havlíček and coauthors (2009) examined the state of ICT deployment (information and communication technologies) by the entities of the agritourism industry in the Czech Republic to determine what information about agritourism is available on the Internet and what form their publication assumes.
Platania (2014) ocenił witryny internetowe gospodarstw agroturystycznych zlokalizowanych na Sycylii (Włochy) wykorzystując model eMICA (Doolin i in. 2002). Wykazał on, że w zbiorze badanych witryn najwięcej było tych, które charakteryzował niski stopień interaktywności. Ponadto większość z nich pełniło jedynie funkcję informacyjną. Zopounidis i współautorzy (2014) zweryfikowali zawartość witryn internetowych greckich gospodarstw agroturystycznych, w tym obecność na stronach: informacji o usłudze, cennika, danych kontaktowych, a także formularza kontaktowego i księgi gości.

Badania witryn internetowych gospodarstw agroturystycznych oraz innych podmiotów świadczących usługi noclegowe na obszarach wiejskich prowadzone są również w oparciu o opinie użytkowników. Herrero i San Martín (2012) na podstawie wywiadów z użytkownikami witryn internetowych prezentujących kwatery agroturystyczne wykazali, że użyteczność witryny jest głównym czynnikiem, który wpływa na zamiar wykorzystania jej do rezerwacji usługi. Udowodnili również, że istotne znaczenie mają interaktywność i łatwość nawigacji, które skłaniają użytkowników do przeglądania witryny. San Martín i Herrero (2012) zbadali proces przyjmowania nowych technologii informacyjnych przez użytkowników witryn internetowych gospodarstw agroturystycznych.

Krzyżanowska (2014) przeanalizowała tendencje zmian w działaniach informacyjno-promocyjnych w turystyce wiejskiej i ich skuteczność. W innej pracy scharakteryzowała cele i narzędzia promocji, źródła informacji o ofercie gospodarstw agroturystycznych preferowane przez turystów i oceniła jakość techniki wykonania witryn wybranych gospodarstw agroturystycznych położonych w woj. podlaskim (Krzyżanowska, Wojtkowski 2012). Dziechciarz (2011) zbadał witryny gospodarstw agroturystycznych z woj. lubuskiego. Ocenił zawartość merytoryczną serwisów oraz możliwość kontaktu i rezerwacji usługi drogą internetową. Analogiczną metodę badań zastosowała Kosmaczewska (2010), która oceniła witryny gospodarstw agroturystycznych położonych w woj. wielkopolskim. Z kolei Stepaniuk (2012) zbadał funkcjonalność witryn internetowych gospodarstw z wschodniej Polski. Król (2015b) poszukiwał zależności pomiędzy techniką wykonania witryn gospodarstw agroturystycznych, a ich widocznością w wynikach wyszukiwania, a Król i Bedla (2015) zbadali 300 witryn internetowych gospodarstw agroturystycznych z Polski i wykazali, że jedynie ich niewielka część dostosowana była do urządzeń mobilnych. Ammirato (2010) przeprowadził badania 176 gospodarstw agroturystycznych z Kalabrii we Włoszech i zwrócił uwagę na powolne wprowadzanie e-handlu przez badane podmioty. Z kolei Havlíček i współautorzy (2009) zbadali stan wykorzystania ICT (ang. information and communication technologies) przez podmioty z branży agroturystycznej w Republice Czeskiej w celu określenia, jakie informacje o agroturystyce są dostępne w Internecie i jaką formę przyjmuje ich publikacja. 


\section{Materials and methods}

There are many measures describing the quality of websites that allow them to be evaluated, described and classified according to various criteria. These measures happen to be expressed with a synthetic point score, often obtained in an automated manner or by expert assessment. The measures that characterize each website include among others: the so-called "Indices of web search trust" that may indicate the "reputation of the site" - its quality and popularity (Dai, Davison 2010). These measures are of technical, engineering and design value. They can be helpful to professionals in the broadly understood Internet marketing industry and serve as one of the parameters characterizing the degree of site optimization for search engines.

There are a number of tools available on the Internet that automatically evaluate selected site parameters, including their design technology. These tools increasingly take the form of applications developed in the client-server architecture, which allow one to carry out a comparative analysis of many projects. Measurements of authority statistics and effectiveness of websites were performed by means of web tools - Complex SEO Audit ${ }^{1}$ and Webspeed Intensys ${ }^{2}$ respectively.

The study was conducted in two stages. The first one verified the values of Trust Rank, Moz Rank, and Page Authority indices, which belong to the most popular "measures of website optimization for search engines". SEO metrics). The second one measured the values of selected site performance indicators, including: time to load the site in the browser window (wait time, so-called "site speed"3) and the total size of a site in megabytes, which are the key factors for site success (Souders 2008, Sanders, Galloway 2013). The ratio of the content to HTML code was also noted Text to HTML Ratio i.e. percentage of the text content in the entire page code. This is another parameter demonstrating the degree of site optimization. On average, according to Webspeed Intensys statistics, the ratio of code to content should should be around $15-20 \%$.

In total, 400 websites of agritourism farms from V4 Countries were analysed, whose addresses were obtained between the 9th and 15th January 2017. The addresses of Slovak farms were obtained from the directory "Zoznam" (zoznam.sk), from the portal "Slovakia.travel" (Národný portál cestovného Slovenska) and from smaller website catalogues. The addresses of Polish farm websites were obtained from the online catalogue "Onet" (katalog.onet. pl) and the Czech sites from the catalogue "infoturistika.cz". Hungarian website addresses were compiled from the directory of the agritourism

1 http://www.seomastering.com (retrieved on 08/01/2017) - the application performs a comprehensive audit of website SEO while analyzing the value of site authority indicators.

2 https://webspeed.intensys.pl (retrieved on 08/01/2017) - the application measures site performance in detail, including the time needed to load a page relative to its size.

3 It determines how quickly users can view a website content and interact with the site.

\section{Materiały i metody}

Istnieje wiele miar opisujących jakość witryn internetowych, które pozwalają je ocenić, opisać i sklasyfikować według różnych kryteriów. Miary te bywają wyrażane syntetyczną notą punktową, często pozyskaną $w$ sposób zautomatyzowany lub w drodze oceny eksperckiej. Do miar charakteryzujących każdą witrynę internetową zaliczyć można m.in. tzw. „wskaźniki zaufania wyszukiwarek internetowych”, które mogą świadczyć o „reputacji witryny” - jej jakości i popularności (Dai, Davison 2010). Miary te mają wartość techniczną, inżynierską, projektową. Mogą być pomocne dla specjalistów z branży szeroko pojętego marketingu internetowego i służyć jako jeden z parametrów charakteryzujących stopień optymalizacji witryny dla wyszukiwarek internetowych.

W Internecie dostępnych jest wiele narzędzi, które w sposób zautomatyzowany oceniają wybrane parametry witryn, w tym technikę ich wykonania. Narzędzia te coraz częściej przyjmują formę aplikacji wykonanych $\mathrm{w}$ architekturze klient-serwer, które pozwalają przeprowadzić analizę porównawczą wielu projektów. Pomiary statystyk autorytetu oraz wydajności witryn wykonano za pomocą aplikacji internetowych, odpowiednio - Complex SEO Audit ${ }^{1}$ oraz Webspeed Intensys ${ }^{2}$.

Badania przeprowadzono $\mathrm{w}$ dwóch etapach. W pierwszym zweryfikowano wartości wskaźników Trust Rank, MozRank oraz Page Authority, które należą do grona najbardziej popularnych „miar stopnia optymalizacji witryny dla wyszukiwarek internetowych" (ang. SEO metrics). W drugim etapie zmierzono wartości wybranych wskaźników wydajności witryn, w tym: czas wczytania witryny w oknie przeglądarki (czas oczekiwania, tzw. „szybkość witryny”3) oraz łączny rozmiar witryny w megabajtach, które należą do podstawowych czynników sukcesu witryny (Souders 2008, Sanders, Galloway 2013). Odnotowano także stosunek treści do kodu HTML (ang. Text to HTML Ratio ), tj. procentową zawartość tekstu w całym kodzie strony. Jest to kolejny parametr oddający stopień optymalizacji witryny. Przeciętnie, według statystyk Webspeed Intensys, stosunek kodu do treści powinien wynosić około $15-20 \%$.

Łącznie analizie poddano 400 witryn internetowych gospodarstw agroturystycznych z krajów V4, których adresy pozyskano w dniach od 9 do 15 stycznia 2017 roku. Adresy gospodarstw słowackich pozyskano z katalogu witryn - „Zoznam” (zoznam. sk), z portalu „Slovakia.travel” (Národný portál cestovného ruchu Slovenska) oraz z mniejszych katalogów witryn. Adresy witryn gospodarstw polskich pozyskano z internetowego katalogu „Onet” (katalog. onet.pl), a witryn czeskich z katalogu „info-turistika. cz". Adresy witryn węgierskich skompletowano z ka-

\footnotetext{
$1 \mathrm{http}: / /$ www.seomastering.com (dostep z dnia 08.01.2017) - aplikacja wykonuje kompleksowy audyt SEO witryn internetowych, analizując jednocześnie wartości wskaźników autorytetu witryny.

2 https://webspeed.intensys.pl (dostęp z dnia 08.01.2017) - aplikacja w szczegółowy sposób mierzy wydajność witryny, w tym czas wczytania strony w odniesieniu do jej rozmiaru.

3 Określa jak szybko użytkownicy mogą zobaczyć zawartość witryny i wejść z nią w interakcję.
} 
association "fatosz.eu" (Falusi és Agriturizmus Országos Szövetsége).

Characteristics of the metrics of the degree of website optimization for search engines

Trust Rank is one of the most powerful indices describing website quality. It is calculated basing on an algorithmic evaluation of selected site parameters, including: age, content uniqueness, number of catalogued pages, popularity (measure of usage), number and quality of incoming links (backlinks). The value of the index ranges from 1 to 10 points, while the rating exceeding 3 points means "high search engine trust to the site", and the rating above 5 points - excellent.

Moz Rank (MR) is calculated on the basis of the algorithmic analysis of the number and quality of incoming links, i.e. those that have been placed on other sites. With some simplification, it can be assumed that the higher the quality of incoming links, the higher the value of the Moz Rank index. MR is expressed as a rating between 0 and 10 points, with its value for an average site oscillating around 3-4 points. Page Authority (PA), like Moz Rank, is an index ranging from 0 to 100 points, which depicts, in a synthetic manner, the quality of inbound links for a given site.

\section{Results and conclusions}

Tests covered 400 websites of the total size of ${ }^{4}$ about $750 \mathrm{MB}$ (according to the Webspeed Intensys testing algorithm). The average time taken to load the site in the browser window was about 2.7 seconds, with $144(36 \%)$ of the sites subject to tests being loaded, according to the Webspeed Intensys testing algorithm, in less than 1 second, and $68(17 \%)$ in the above 5 seconds (tab. 1). Such a long waiting period for the presentation of the homepage may discourage users from viewing it. It also leads us to conclusions of the low dynamics of browsing the pages that make up its structure (so-called "subpages").

The total time of first loading of all websites in a web browser window was about 18 minutes (approx. 1092s), while the total reloading time was slightly shorter, and was about 14 minutes (approx. 831s). It testifies indirectly to the technical aspects of the design of the tested sites - in 101 cases (25\%) it can be estimated that more than $70 \%$ of the data that constitutes the site and is being retrieved by the recipient's device (according to the Webspeed Intensys testing algorithm) is written on it (e.g. in the folder Temporary Internet Files), so during the next visit the data is not re-downloaded from the server.

The value of the test site quality indices (according to test algorithms) is varied, but mostly very low. In the case of as many as 331 sites (approx. 83\%) the reported Trust Rank was lower than 1 point. This may

\footnotetext{
4 The term "total website size" is used here as a way of simplification. This size describes the amount of data uploaded by the network during the first loading of a website in a browser window, as measured by the testing algorithm. It does not have to be the same as the total size of the site, as not all site components are loaded during the presentation of the homepage.
}

talogu stowarzyszenia agroturystycznego „fatosz.eu” (Falusi és Agroturizmus Országos Szövetsége).

Charakterystyka mierników stopnia optymalizacji witryny dla wyszukiwarek internetowych

Trust Rank to jedna z syntetycznych miar opisujących jakość witryn internetowych. Jest obliczany na podstawie algorytmicznej oceny wybranych parametrów witryny, w tym: wieku, unikalności treści, liczby skatalogowanych stron, popularności (miar użytkowania), liczby i jakości linków przychodzących (ang. backlinks). Wartość wskaźnika plasowana jest w przedziale od 1 do 10 punktów, przy czy ocena przekraczająca 3 punkty oznacza „duże zaufanie wyszukiwarek do witryny", a ocena powyżej 5 punktów - doskonałe.

MozRank (MR) obliczany jest na podstawie algorytmicznej analizy liczby i jakości linków przychodzących, tj. takich, które zostały zamieszczone na stronach innych witryn. W pewnym uproszczeniu można zatem przyjąć, że im wyższa jakość linków przychodzących, tym wyższa wartość wskaźnika MozRank. MR jest wyrażany notą z przedziału od 0 do 10 punktów, przy czym jej wartość dla przeciętnej witryny oscyluje wokół 3-4 punktów. Page Authority (PA), podobnie jak MozRank, to wskaźnik oddający w sposób syntetyczny, w skali od 0 do 100 punktów, jakość linków przychodzących dla danej witryny.

\section{Wyniki i wnioski}

Testom poddano 400 witryn internetowych o łącznym rozmiarze ${ }^{4}$ około $750 \mathrm{MB}$ (według algorytmu testującego Webspeed Intensys). Przeciętny czas pierwszego wczytania witryny w oknie przeglądarki wyniósł około 2,7 sekundy, przy czym 144 (36\%) z testowanych witryn wczytana została, według algorytmu testującego Webspeed Intensys, w czasie poniżej 1 sekundy, i aż 68 (17\%) w czasie powyżej 5 sekund (tab. 1). Tak długi czas oczekiwania na prezentację strony głównej może zniechęcić użytkownika do jej przeglądania. Pozwala także wnioskować o małej dynamice przeglądania stron składających się na jej strukturę (tzw. „podstron”).

Łączny czas pierwszego wczytania wszystkich witryn w oknie przeglądarki internetowej wyniósł około 18 minut (ok. 1092s), podczas gdy łączny czas ich ponownego wczytania był nieco krótszy, i wyniósł około 14 minut (ok. 831s). Świadczy to pośrednio o technicznych aspektach budowy testowanych witryn - w 101 przypadkach (25\%) szacować można, że ponad 70\% danych, które składają się na witrynę, i są pobierane przez urządzenie odbiorcy (według algorytmu testującego Webspeed Intensys), jest zapisywanych na tym urządzeniu (np. w folderze Temporary Internet Files), przez co podczas następnej wizyty dane te nie są ponownie pobierane z serwera.

Wartości wskaźników jakości badanych witryn (według algorytmów testujących) są zróżnicowane,

\footnotetext{
4 Pojęcie „łącznego rozmiaru witryn” jest tu użyte w pewnym uproszczeniu. Wielkością tą opisano ilość danych przesłanych siecią w trakcie pierwszego wczytania witryny w oknie przeglądarki, zmierzoną przez algorytm testujący. Nie musi być ona tożsama $\mathrm{z}$ całkowitym rozmiarem witryny, bowiem nie wszystkie części składowe witryn są wczy tywane w trakcie prezentacji strony głównej.
} 
Table 1. Loading time and total site size according to the Webspeed Intensys testing algorithm

Tabela 1. Czas wczytywania oraz łączny rozmiar witryn według algorytmu testującego Webspeed Intensys

\begin{tabular}{|c|c|c|c|c|c|}
\hline \multirow{2}{*}{$\begin{array}{c}\text { First loading (number of sites)/ } \\
\text { Pierwsze wczytanie (liczba witryn) } \\
\text { Time of site loading (s)/ } \\
\text { Czas wczytywania witryny (s) }\end{array}$} & \multicolumn{4}{|c|}{ Country/Kraj } & \multirow{2}{*}{$\begin{array}{l}\text { Total/ } \\
\text { Łącznie }\end{array}$} \\
\hline & $\begin{array}{c}\text { The Czech } \\
\text { Republic } \\
\text { Czechy }\end{array}$ & $\begin{array}{l}\text { Hungary/ } \\
\text { Węgry }\end{array}$ & $\begin{array}{l}\text { Poland/ } \\
\text { Polska }\end{array}$ & $\begin{array}{l}\text { Slovakia/ } \\
\text { Słowacja }\end{array}$ & \\
\hline $0-1$ & 33 & 34 & 43 & 34 & 144 \\
\hline $1,01-3$ & 30 & 31 & 32 & 32 & 125 \\
\hline $3,01-5$ & 15 & 14 & 15 & 19 & 63 \\
\hline$>5$ & 22 & 21 & 10 & 15 & 68 \\
\hline Total/Łącznie (s) & 248.983 & 325.938 & 237.729 & 279.686 & 1092.336 \\
\hline $\begin{array}{l}\text { Reloading (number of sites)/ } \\
\text { Powtórne wczytanie (liczba witryn) }\end{array}$ & $\begin{array}{c}\text { The Czech } \\
\text { Republic/ } \\
\text { Czechy }\end{array}$ & $\begin{array}{l}\text { Hungary/ } \\
\text { Węgry }\end{array}$ & $\begin{array}{l}\text { Poland/ } \\
\text { Polska }\end{array}$ & $\begin{array}{l}\text { Slovakia/ } \\
\text { Słowacja }\end{array}$ & $\begin{array}{l}\text { Total/ } \\
\text { Łącznie }\end{array}$ \\
\hline $0-1$ & 52 & 44 & 55 & 52 & 203 \\
\hline $1,01-3$ & 19 & 27 & 25 & 21 & 92 \\
\hline $3,01-5$ & 10 & 11 & 11 & 18 & 50 \\
\hline$>5$ & 19 & 18 & 9 & 9 & 55 \\
\hline Total/Łącznie (s) & 186.001 & 276.413 & 169.959 & 198.703 & 831.076 \\
\hline Total size/Łączny rozmiar (MB) & 145.71 & 291.96 & 133.39 & 178.65 & 749.71 \\
\hline
\end{tabular}

Source: Author's own elaboration (as of 08/01/2017).

Źródło: Opracowanie własne (stan z dnia 08.01.2017).

testify to a very small, insignificant "trust" of search engines for the tested sites. The low value of the index indicates a relatively low quality of the site, including a small number and quality of incoming links, as well as a low number of visits. In addition, only 14 sites (3.5\%) were reported, which were characterized by a relatively high Trust Rank index. Yet there are no significant differences between farm websites from different V4 countries.

Most sites tested are characterized by an average value of Moz Rank index, although the values of this parameter are slightly better than the measurements of the Trust Rank index. This may be due to the algorithm calculating Moz Rank, which primarily takes into account the quality of incoming links. The tested sites were also characterized by a low value of thePage Authority index. In 345 cases (slightly over $86 \%$ ), it reached a relatively low value, ranging from 11 to 40 points. Moreover, in 38 cases (almost 10\%), the index value was less than 10 points (Tab. 2).

In the set of the tested sites, the ones whose Trust Rank index does not exceed 0.99 points (out of 10 possible) and those whose Moz Rank index fluctuates between 3 and 4.99 points clearly dominate (Figure 1).

In the set of the tested websites, 222 sites (55\%) were recorded with an average content-to-code ratio and 65 sites (16\%) presented definitely very little content. Therefore, this parameter is evaluated unfavourably in the tests. Only in 18 cases there was a significant advantage of content over the code (Tab. 3). jednak w większości bardzo niskie. W przypadku aż 331 witryn (ok. 83\%) odnotowano wskaźnik Trust Rank mniejszy od 1 punktu. Może to świadczyć o bardzo małym, znikomym „zaufaniu” wyszukiwarek do testowanych witryn. Niska wartość wskaźnika świadczy o relatywnie niskiej jakości witryny, w tym niewielkiej liczbie i jakości linków przychodzących, a także małej liczbie odwiedzin. Ponadto odnotowano jedynie 14 witryn $(3,5 \%)$, które charakteryzował relatywnie wysoki wskaźnik Trust Rank. Przy czym brak tu istotnego zróżnicowania pomiędzy witrynami gospodarstw z różnych krajów V4.

Większość testowanych witryn charakteryzowała przeciętna wartość wskaźnika MozRank, choć wartości pomiarów tego parametru wypadły nieco lepiej w porównaniu z pomiarami wskaźnika Trust Rank. Może to wynikać z algorytmu wyliczającego MozRank, który uwzględnia przede wszystkim jakość linków przychodzących. Testowane witryny cechowała także niska wartość wskaźnika Page Authority. Aż w 345 przypadkach (nieco ponad 86\%) osiągną on relatywnie niską wartość, z przedziału od 11 do 40 punktów. Ponadto w 38 przypadkach (niecałe $10 \%)$ wartość wskaźnika była mniejsza od 10 punktów (tab. 2).

W zbiorze testowanych witryn wyraźnie dominują te, których wskaźnik Trust Rank nie przekracza 0,99 punktu (na 10 możliwych) oraz te, których wskaźnik MozRank oscyluje w przedziale od 3 do 4,99 punktu (rysunek 1).

Z zbiorze testowanych witryn odnotowano 222 witryny (55\%) o przeciętnym stosunku treści do kodu i 65 witryn (16\%), które prezentowały zdecydowanie za mało treści. Parametr ten wypada więc w testach niekorzystnie. Jedynie w 18 przypadkach odnotowano dużą przewagę treści nad kodem (tab. 3). 
Table 2. "Website authority" according to the testing algorithm Complex SEO Audit

Tabela 2. „Autorytet witryn” według algorytmu testującego Complex SEO Audit

\begin{tabular}{|c|c|c|c|c|c|}
\hline \multirow{2}{*}{$\begin{array}{c}\text { Quality indicator/ } \\
\text { Wskaźnik jakości } \\
\text { Trust Rank }\end{array}$} & \multicolumn{4}{|c|}{ Country/Kraj } & \multirow[b]{2}{*}{$\begin{array}{c}\text { Total/ } \\
\text { Łącznie }\end{array}$} \\
\hline & $\begin{array}{c}\text { The Czech } \\
\text { Republic } \\
\text { Czechy } \\
\end{array}$ & $\begin{array}{c}\text { Hungary/ } \\
\text { Węgry }\end{array}$ & $\begin{array}{c}\text { Poland/ } \\
\text { Polska }\end{array}$ & $\begin{array}{l}\text { Slovakia/ } \\
\text { Słowacja }\end{array}$ & \\
\hline 0 & 3 & 3 & 11 & 6 & 23 \\
\hline $0-0.99$ & 70 & 92 & 84 & 85 & 331 \\
\hline $1-2.99$ & 16 & 4 & 5 & 7 & 32 \\
\hline 3-4.99 & 7 & 0 & 0 & 1 & 8 \\
\hline$>5$ & 4 & 1 & 0 & 1 & 6 \\
\hline Moz Rank & $\begin{array}{c}\text { The Czech Repu- } \\
\text { blic/ } \\
\text { Czechy } \\
\end{array}$ & $\begin{array}{l}\text { Hungary/ } \\
\text { Węgry }\end{array}$ & $\begin{array}{c}\text { Poland/ } \\
\text { Polska }\end{array}$ & $\begin{array}{l}\text { Slovakia/ } \\
\text { Słowacja }\end{array}$ & $\begin{array}{c}\text { Total/ } \\
\text { Łącznie }\end{array}$ \\
\hline 0 & \begin{tabular}{|l|}
7 \\
\end{tabular} & 8 & 39 & 13 & 67 \\
\hline $0-0.99$ & 0 & 0 & 0 & 0 & 0 \\
\hline $1-2.99$ & 2 & 1 & 1 & 0 & 4 \\
\hline 3-4.99 & 69 & 79 & 56 & 70 & 274 \\
\hline$>5$ & 22 & 12 & 4 & 17 & 55 \\
\hline Page Authority & $\begin{array}{c}\text { The Czech Repu- } \\
\text { blic/ } \\
\text { Czechy }\end{array}$ & $\begin{array}{l}\text { Hungary/ } \\
\text { Węgry }\end{array}$ & $\begin{array}{c}\text { Poland/ } \\
\text { Polska }\end{array}$ & $\begin{array}{l}\text { Slovakia/ } \\
\text { Słowacja }\end{array}$ & $\begin{array}{l}\text { Total/ } \\
\text { Łącznie }\end{array}$ \\
\hline $1-10$ & 6 & 5 & 17 & 10 & 38 \\
\hline $11-40$ & 83 & 92 & 81 & 89 & 345 \\
\hline $41-70$ & 11 & 3 & 2 & 1 & 17 \\
\hline$>70$ & 0 & 0 & 0 & 0 & 0 \\
\hline
\end{tabular}

Source: Author's own elaboration (state as at 08/01/2017).

Źródło: Opracowanie własne (stan z dnia 08.01.2017).

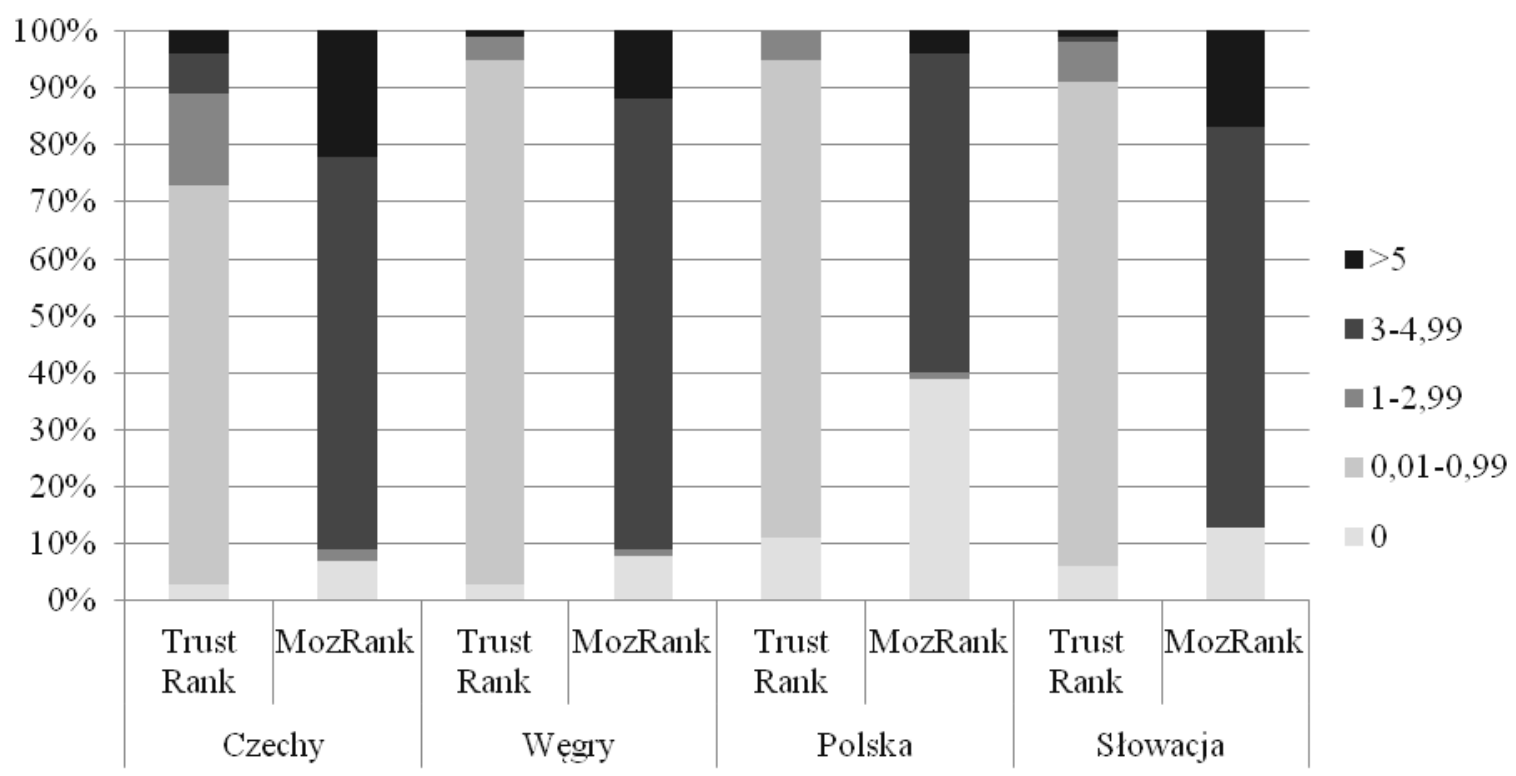

Figure 1. Values of Trust Rank and Moz Rank indices for websites of agritourism farms from particular V4 countries Rysunek 1. Wartości wskaźników Trust Rank i MozRank dla witryn internetowych gospodarstw agroturystycznych poszczególnych krajów V4

Source: Author's research.

Źródło: Badania własne. 
Table 3. The ratio of the published content to the code that it is "supported"

Tabela 3. Stosunek opublikowanej treści do kodu, który ją „obsługuje”

\begin{tabular}{|c|c|c|c|c|c|}
\hline \multirow{2}{*}{$\begin{array}{c}\text { Quality measure/ Miara jakości } \\
\text { Content-to-code ratio/ } \\
\text { Stosunek treści do kodu }\end{array}$} & \multicolumn{4}{|c|}{ Country/Kraj } & \multirow[b]{2}{*}{$\begin{array}{c}\text { Total/ } \\
\text { Łącznie }\end{array}$} \\
\hline & $\begin{array}{l}\text { The Czech } \\
\text { Republic } \\
\text { Czechy }\end{array}$ & $\begin{array}{c}\text { Hungary/ } \\
\text { Węgry }\end{array}$ & $\begin{array}{c}\text { Poland/ } \\
\text { Polska }\end{array}$ & $\begin{array}{l}\text { Slovakia/ } \\
\text { Słowacja }\end{array}$ & \\
\hline 0 & 0 & 2 & 3 & 2 & 7 \\
\hline $1-10$ & 9 & 16 & 19 & 21 & 65 \\
\hline $11-29$ & 54 & 57 & 60 & 51 & 222 \\
\hline $30-50$ & 32 & 16 & 18 & 22 & 88 \\
\hline $51-70$ & 5 & 9 & 0 & 4 & 18 \\
\hline
\end{tabular}

Source: Author's research.

Źródło: Opracowanie własne.

\section{Conclusions}

Websites of agritourism farms in the Visegrad Group countries are characterized by low values of global trust indices and relatively low performance. The speed of webpage affects the perception and evaluation of the website. It may have a direct impact on whether the user decides to view and visit it again. It may contribute to goal conversion (site effectiveness, results achieved). In addition, the conducted measurements allow the conclusion, that the majority of the tested websites are not indicated by any valuable links, or that there are very few such links (few sites on the Internet recommend the tested websites). This in turn results in the phenomenon of a specific "vicious circle". Sites that are characterized by mostly average or low amount of content are ranked at distant positions in search results. They are therefore barely visible or not visible to the public at all. Few valuable (popular) sites refer their users to them, which deepens their inaccessibility. Therefore, it can be concluded that these sites, despite their global potential, have a local impact. Their existence is known to a small number of people, and their visibility on the Internet is negligible or nonexistent. Websites published in such manner do not fulfil their function.

Low values of authority indices for the tested sites may testify to their poor quality (technical and substantive), poor visibility in search results, and lack of recommendations issued by other valuable sites. They may also signify that the tested sites play a small role in the promotion of agritourism farms and require optimization. The basis for solving this problem lies in adequately edited and formatted text, enriched with multimedia, improvement of webpage design technology, and extensive promotional activities. Only a website rich in content will be recommended, and can reach a high position in the search results, by means of which it will be visible to tourists looking for accommodation online.

\section{Podsumowanie}

Witryny gospodarstw agroturystycznych krajów Grupy Wyszehradzkiej charakteryzowały niskie wartości globalnych wskaźników zaufania i relatywnie niska wydajność. Szybkość witryny internetowej wpływa na postrzeganie i ocenę serwisu. Może mieć bezpośredni wpływ na to, czy użytkownik zdecyduje się ją przeglądać i ponownie odwiedzić. Może mieć przełożenie na konwersję celu (efektywność witryny, osiągane rezultaty). Ponadto przeprowadzone pomiary pozwalają wnioskować, że do większości testowanych witryn nie prowadzą żadne wartościowe linki, lub takich linków jest bardzo mało (niewiele popularnych w Internecie witryn rekomenduje testowane witryny). Wywołuje to poniekąd zjawisko swoistego „błędnego koła”. Witryny charakteryzujące się przeważnie przeciętną lub niewielką ilością treści są plasowane na odległych miejscach w wynikach wyszukiwania. Są więc mało widoczne, lub w ogóle niewidoczne dla odbiorców. Niewiele wartościowych (popularnych witryn) odsyła do nich swoich użytkowników co pogłębia ich niedostępność. Można zatem wnioskować, że witryny te, pomimo globalnego potencjału, oddziaływują lokalnie. 0 ich istnieniu wie niewielka liczba osób, a ich widoczność w Internecie jest znikoma lub żadna. Tak opublikowane witryny nie spełniają swojej funkcji.

Niskie wartości wskaźników autorytetu testowanych witryn mogą świadczyć o ich niskiej jakości (technicznej i mery torycznej), niewielkiej widoczności $\mathrm{w}$ wynikach wyszukiwania oraz braku rekomendacji płynących z innych, wartościowych witryn. Mogą także oznaczać, że testowane witryny pełnią niewielką rolę w promocji gospodarstw agroturystycznych i wymagają optymalizacji. U podstawy rozwiązania tego problemu leży odpowiednio zredagowany i sformatowany tekst, wzbogacony przekazem multimedialnym, poprawa techniki wykonania witryn, a także szeroko zakrojone działania promocyjne. Tylko witryna bogata $w$ treści będzie polecana, rekomendowana i może osiągnąć wysokie miejsce w wynikach wyszukiwania, przez co będzie widoczna dla turystów poszukujących ofert noclegu w Internecie. 


\section{Acknowledgements}

The research was financed by the Proprietary Scholarship Fund for Academic Teachers of the Agricultural University of Hugon Kołłątaj in Kraków.

\section{Podziękowania}

Badania sfinansowano z Własnego Funduszu Stypendialnego dla nauczycieli akademickich Uniwersytetu Rolniczego im. Hugona Kołłątaja w Krakowie.

\section{References/Literatura:}

1. Abrham J. (2014), Clusters in tourism, agriculture and food processing within the Visegrad Group. Agric. Econ. - Czech, no. 60(5), p. 208-218.

2. Ammirato S. (2010), An empirical study of agritourism evolution and e-commerce adoption challenges. Information Technology \& Tourism, no. 12(1), p. 89-104. doi: 10.3727/109830510X12747489979664.

3. Beldona S., Cai L. A. (2006), An Exploratory Evaluation of Rural Tourism Websites. Journal of Convention \& Event Tourism, no. 8(1), p. 69-80. doi: https://doi.org/10.1300/J452v08n01_04

4. Dai N., Davison B. D. (2010), Freshness matters: inflowers, food, and web authority, In: Proceedings of the 33rdinternational ACM SIGIR conference on Research and development in information retrieval. p. 114-121. ACM. doi: 10.1145/1835449.1835471.

5. Dangerfield M. (2008), The Visegrad Group in the expanded European Union: From preaccession to postaccession cooperation. East European Politics \& Societies, no. 22(3), p. 630-667. doi: 10.1177/0888325408315840.

6. Doolin B., Burgess L., Cooper J. (2002), Evaluating the use of the Web for tourism marketing: a case study from New Zealand. Tourism Management, no. 23(5), p. 557-561. doi: 10.1016/S0261-5177(02)00014-6.

7. Dziechciarz T. (2011), Wykorzystanie witryn internetowych i poczty elektronicznej w marketingu agroturystyki na przykładzie województwa lubelskiego. Nierówności Społeczne a Wzrost Gospodarczy, nr 23, s. 30-39.

8. Havlíček Z., Lohr V., Šmejkalová M., Grosz J., Benda P. (2013), Agritourism Farms -Evaluation of Their Websites Quality and Web 2.0. AGRIS on-line Papers in Economics and Informatics, no. 5(1), p. 31-38.

9. Havlíček Z., Benda P., Lohr V. (2009), Agritourism Web Presentation Evaluation. Praha: Agrarian Perspectives XVIII, PEF CULS Prague.

10. Havlíček Z., Lohr V., Benda P. (2009), ICT and agritourism in Czech Republic. Applied Studies in Agribusiness and Commerce, no 3, p. 800-807. doi: 10.19041/Apstract/2009/3-4/10.

11. Herrero Á., San Martín H. (2012), Developing and testing a global model to explain the adoption of websites by users in rural tourism accommodations. International Journal of Hospitality Management, no. 31(4), p. 1178-1186. doi: 10.1016/j. ijhm.2012.02.005.

12. Jankowski J. (2011), Identyfikacja elementów wpływajacych na efektywność witryn internetowych. Zeszyty Naukowe Uniwersytetu Szczecińskiego. Ekonomiczne Problemy Usług, (67 Drogi dochodzenia do społeczeństwa informacyjnego. Stan obecny, perspektywy rozwoju i ograniczenia. T. 1), s. 591-600.

13. Kosmaczewska J. (2010), Witryna internetowa jako narzędzie kreowania konkurencyjności w agroturystyce. Acta Scientiarum Polonorum, Oeconomia, nr 9(4), s. 225-232.

14. Król K. (2015a), Funkcja witryn internetowych gospodarstw agroturystycznych według modelu wdrożenia technologii internetowej SMWTI. Acta Sci. Pol. Formatio Circumiectus, nr 14(2), s. 111-123. doi: 10.15576/ASP.FC/2015.14.2.111.

15. Król K. (2015b), Ocena dostępności ofert turystycznych małych gospodarstw rolnych w Internecie. Problemy Drobnych Gospodarstw Rolnych - Problems of Small Agricultural Holdings, nr 4, s. 5-23. doi: 10.15576/PDGR/2015.4.5.

16. Król, K. (2017), Konwersja celu w internetowej sprzedaży produktów turystyki wiejskiej. Problemy Drobnych Gospodarstw Rolnych - Problems of Small Agricultural Holdings, 2, s. 33-40. doi: http://dx.doi.org/10.15576/PDGR/2017.2.33..

17. Król K. (2016), Wpływ optymalizacji witryn internetowych na promocję turystyki wiejskiej w sieci. Problemy Drobnych Gospodarstw Rolnych - Problems of Small Agricultural Holdings, no 3, s. 57-71. doi: 10.15576/PDGR/2016.3.57.

18. Król K., Bedla D. (2015), Ocena wykorzystania technologii responsywności w projektach witryn internetowych gospodarstw agroturystycznych. Problemy Drobnych Gospodarstw Rolnych - Problems of Small Agricultural Holdings, nr 3, s. 53-65. doi: 10.15576/PDGR/2015.3.53.

19. Krzyżanowska K. (2014), Tendencje zmian $w$ działaniach informacyjno-promocyjnych $w$ turystyce wiejskiej i ich skuteczność. Zeszyty Naukowe Szkoły Głównej Gospodarstwa Wiejskiego. Ekonomika i Organizacja Gospodarki Żywnościowej, nr 107, s. 57-67.

20. Krzyżanowska K., Wojtkowski R. (2012), Rola internetu w promocji usług agroturystycznych. Studia Ekonomiczne i Regionalne, nr 5(1), s. 48-57.

21. Platania M. (2014), Agritourism farms and the web. An exploratory evaluation of their websites. Agris On-line Papers in Economics and Informatics, no. 6(3), p. 51-58.

22. San Martín H., Herrero Á. (2012), Influence of the user's psychological factors on the online purchase intention in rural tourism: Integrating innovativeness to the UTAUT framework. Tourism Management, no. 33(2), p. 341-350. doi: https://doi.org/ 10.1016/j.tourman.2011.04.003

23. Sanders J., Galloway L. (2013), Rural small firms' website quality in transition and market economies. Journal of Small Business and Enterprise Development, no. 20(4), p. 788-806. doi: 10.1108/JSBED-01-2012-0009.

24. Souders S.(2008), High-performancewebsites.Communicationsof the ACM, no.51(12), p.36-41.doi: 10.1145/1409360.1409374.

25. Stapaniuk K. (2012), Funkcjonalność witryn internetowych gospodarstw agroturystycznych we Wschodniej Polsce. Ekonomia i Zarządzanie, nr 4(1), s. 92-101.

26. Törő C., Butler E., Grúber K. (2014), Visegrád: The Evolving Pattern of Coordination and Partnership After EU Enlargement. Europe-Asia Studies, no. 66(3), p. 364-393. doi: 10.1080/09668136.2013.855392.

27. Zopounidis C., Lemonakis C., Andreopoulou Z., Koliouska C. (2014), Agrotourism Industry Development through Internet Technologies: A Multicriteria Approach. Journal of Euromarketing, no 23(4), p. 45-67. doi: 10.9768/0023.04.045. 